\title{
Changes of gene expression of iron regulatory proteins during turpentine oil-induced acute-phase response in the rat
}

\author{
Nadeem Sheikh, Jozsef Dudas and Giuliano Ramadori
}

In the present study, turpentine oil was injected in the hind limb muscle of the rat to stimulate an acute-phase response (APR). The changes in the gene expression of cytokines and proteins known to be involved in the iron regulatory pathway were then studied in the liver and in extra-hepatic tissue. In addition to the strong upregulation of interleukin-6 (IL-6) and IL-1 $\beta$ observed in the inflamed muscle, an upregulation of the genes for IL1- $\beta$ and tumor necrosis factor- $\alpha$, but not IL- 6 , were detectable in the liver. Hepatic Hepc gene expression increased to a maximum at $6 \mathrm{~h}$ after the onset of APR. An upregulation of transferrin, transferrin receptor 1 (TfR1), TfR2, ferritin- $\mathrm{H}$, iron responsive element binding protein-1 (IRP1), IRP2 and divalent metal transporter gene expression was also found. Hemojuvelin (Hjv)-, ferroportin 1-, Dcytb-, hemochromatosis-gene- and hephaestin gene expression was downregulated. Hepcidin (Hepc) gene expression was not only detectable in extra-hepatic tissues such as heart, small intestine, colon, spleen and kidney but it was also upregulated under acute-phase conditions, with the Hjv gene being regulated antagonistically. Fpn-1 gene expression was downregulated significantly in heart, colon and spleen. Most of the genes of the known proteins involved in iron metabolism are expressed not only in the liver but also in extra-hepatic tissues. Under acute-phase conditions, acute-phase cytokines (eg IL-6) may modulate the gene expression of such proteins not only in the liver but also in other organs.

Laboratory Investigation (2007) 87, 713-725; doi:10.1038/labinvest.3700553; published online 9 April 2007

KEYWORDS: acute-phase response; extrahepatic hepcidin expression; hepcidin; hypoferremia; iron; turpentine oil

Iron is vital for almost every organism by participating in a wide variety of metabolic processes. ${ }^{1}$ The redox ability of iron, however, can lead to the production of oxygen free radicals, which can damage various cellular components. For this reason, the iron levels must be tightly regulated. ${ }^{2}$ Under inflammatory conditions, a diversion of iron traffic occurs from the circulation to storage sites of reticuloendothelial system so as to minimize the availability of this essential element. $^{3}$

The acute-phase response (APR) is the defense reaction and is aimed to restrict the area of damage on one side and to eliminate, or at least isolate, the damaging agent on the other side. Every agent that leads to loss of the integrity of tissues induces a local reaction known as inflammation, which influences the iron balance in the whole organism. ${ }^{4}$ Synthesis of the major acute-phase proteins can increase to 1000 -fold over normal levels during acute-phase condition. This group includes serum amyloid $\mathrm{A}$ and either C-reactive protein in humans or its homolog in mice, serum amyloid P component. $^{5}$

The acute-phase cytokines released into the vascular system by the activated inflammatory cells $s^{3,6,7}$ are responsible for the more generalized signs or symptoms of the $\mathrm{APR}^{8}$ and for the dramatic changes in protein synthesis in the liver. As the liver is the main organ of the reticuloendothelial system, it may probably be the organ responsible for the hypoferremia under APR. How iron is transported into the liver, which receptors are involved in the uptake and what is the real fate of the iron during inflammation are still a matter of debate.

The recently discovered hormone hepcidin (Hepc), previously reported as LEAP-1 (liver-expressed antimicrobial peptide), ${ }^{9}$ is a 25 -amino-acid, $2-3 \mathrm{kDa}$, cationic peptide ${ }^{10}$ and is an acute-phase protein mainly synthesized by hepatocytes. It is a major regulator of iron balance in the intestinal mucosa and it seems to have a significant role during inflammation by inducing hypoferremia. ${ }^{11}$ In addition, it

Division of Gastroenterology and Endocrinology, Department of Internal Medicine, Georg-August-University, Göttingen, Germany

Correspondence: Professor G Ramadori, MD, Department of Internal Medicine, University Hospital, Göttingen, Robert Koch Str. 40 , 37075 Göttingen, Germany.

E-mail: gramado@med.uni-goettingen.de

Received 07 February 2007; accepted 18 February 2007 
regulates maternal-fetal iron transport across the placenta, ${ }^{12}$ affects the release of iron from hepatic stores and from macrophages and is, involved in the recycling of iron from hemoglobin, by directly binding to the cellular iron exporter ferroportin-1. ${ }^{13,14}$ Lack of Hepc-gene results in iron overload, ${ }^{15}$ which suggests that the peptide can repress iron absorption. Its production is increased during inflammation and in iron overload conditions. ${ }^{16}$ During the APR, however, Hepc expression changes more rapidly than the expression of iron transporters. ${ }^{17}$

The hemochromatosis genes HFE, TfR2 and hemojuvelin (Hjv) potentially facilitate the transcription of HAMP (hepcidin antimicrobial peptide). HFE forms complex with transferrin receptor 1 (TfR1) in duodenal crypt enterocytes, ${ }^{18}$ liver homogenates and transfected cell lines. ${ }^{19}$ Animals bearing TfR2 mutations developed periportal hepatic iron loading, splenic iron sparing and elevated serum transferrin (Tf) saturations. ${ }^{20}$ Hjv deficiency results in iron overload and failure of Hepc gene expression in response to dietary or injected iron. ${ }^{21}$ However, the upregulation of Hepc gene expression in response to acute inflammation induced by either lipopolysaccharide or its downstream products was unaltered in the Hjv-deficient mice. ${ }^{21}$

Tf carries iron from the intestine, reticuloendothelial system and liver parenchymal cells to all proliferating cells in the body. Diferric Tf interacts with the TfR 1 and is internalized by receptor-mediated endocytosis. ${ }^{22}$ Duodenal cytochrome $b$ (Dcytb), divalent-metal transporter 1 (DMT1), ferroportin-1 (Fpn1) and hephaestin (Heph), ${ }^{23-27}$ are major proteins involved in iron absorption. Fpn1 is regulated by Hepc during inflammatory conditions. Hepc binds and causes internalization and degradation of Fpn1; in turn, the cells then lack a transporter for iron. It has been postulated that the post-translational regulation of Fpn1 by Hepc may complete a homeostatic loop regulating iron plasma levels and the tissue distribution of iron. ${ }^{28-30}$

Since an excess of free iron catalyzes the Fenton reaction, most of the intracellular iron is sequestered in the iron storage protein ferritin. ${ }^{31}$ Ferritin-H mRNA is regulated by iron at the translational level. Ferritin-H RNA is present as stored messengers in the cytoplasm and recruited to the ribosomes when iron levels are increased. Iron-induced translational activation of ferritin-H, TfR1 and DMT1 is mediated by an RNA stem-loop called iron responsive element(s) (IREs). The cytoplasmic iron responsive elements (IRE) and iron responsive element binding protein (IRP) interact with the iron-responsive elements of mRNA. The iron status of the cell determines the ability of the IRP to bind to IRE. The IRP plays a central role in cellular iron homeostasis by regulating ferritin mRNA translation and TfR1 mRNA stability. ${ }^{32,33}$

To study pathophysiology of APR, two main models have been used: endotoxemia of the mouse induced systemically, which simulates infection with Gram-negative bacteria, and induction of a sterile muscle abscess in the rat by the intramuscular or subcutaneous injection of turpentine oil, which causes a local inflammation with a subsequent systemic induction of the cytokine-mediated APR; $;^{5,8}$ however, the two models differ significantly. Endotoxin administered intravenously or intraperitoneally reaches the liver and induces local cytokine release whereas the intramuscular injection of turpentine oil (TO) induces a local recruitment of inflammatory cells, which release acute-phase cytokines. ${ }^{6,7}$ In both the cases, the changes in protein synthesis observed in the liver are due to those cytokines (interleukin-6 (IL-6), IL- $1 \beta$ and tumor necrosis factor- $\alpha$ (TNF- $\alpha)$ ).

In the present study, we used TO-induced APR and studied the changes in the gene expression of iron regulatory proteins not only in the liver but also in several other organs. We demonstrate that the genes of the major iron regulatory proteins are expressed not only in the liver but also in several other organs. Furthermore, we demonstrate that the changes in the gene expression of the iron regulatory proteins observed in the liver may also be observed in other organs. These changes are most probably induced by the acute-phase cytokine(s) (eg IL-6) synthesized at the site of injury.

\section{MATERIALS AND METHODS \\ Animals}

Male Wistar rats of about 170-200 g body weight were purchased from Harlan-Winkelmann (Brochen, Germany). The rats were kept under standard conditions with $12 \mathrm{~h}$ light/dark cycles and ad libitum access to fresh water and food pallets. All animals were taken care according to the institutional guidelines, the German convention for the protection of animals and NIH guidelines.

\section{Materials}

All the chemicals used were of analytical grade and were purchased from commercial sources as indicated below: medium M199 from Biochroma (Berlin, Germany); penicillin-streptomycin and L-glutamine from Gibco (Scotland); nucleospin RNA II from Macherey-Nagel (Duren, Germany) for isolation of RNA from the cells; real-time polymerase chain reaction (PCR) primers, primers for Northern blot from MWG biotech, M-MLV reverse transcriptase, reverse transcription buffer and 0.1M DTT, platinum Sybr green qPCR-UDG mix from Invitrogen, dNTPs, protector RNase inhibitor, bovine insulin, Klenow enzyme, primer oligo(DT) ${ }_{15}$ for cDNA synthesis and salmon sperm DNA from Roche (Mannheim, Germany); $\alpha_{-}{ }^{32} \mathrm{P}$-labelled deoxycytidine triphosphate (specific activity $3000 \mathrm{Ci} / \mathrm{mmol}$ ), NICK TM columns and Hybond N nylon membranes from Amersham Pharmacia Biotech (Freiburg, Germany); hybridization solution QuickHyb from Stratagene (Germany), iron ferrozine from Rolf Greiner BioChemica (Flacht, Germany) and Quantikine ${ }^{\circledR}$ enzyme linked immunosorbent assay (ELISA) kits from R\&D systems (IL-6, IL-1- $\beta$, TNF- $\alpha$ and interferon- $\gamma$ (IFN- $\gamma$ ) and pro-Hepc from DRG International (Marburg, Germany). All other reagents and chemicals were from 
Sigma-Aldrich (Munich, Germany) or Merck (Darmstadt, Germany).

\section{Induction of Acute-Phase Reaction}

APR was induced in ether-anesthetized rats by intramuscular injection of $5 \mathrm{mg} / \mathrm{kg}$ TO in both right and left hind limbs of the animals. Control animals were not given any injection. Animals were killed $0.5,1,2,4,6,12$ and $24 \mathrm{~h}$ after TO injection under pentobarbital anesthesia. Different organs as well as hind limb muscle tissue including the TO-injected area were excised, rinsed with physiological sodium saline, snap frozen in liquid nitrogen and stored at $-80^{\circ} \mathrm{C}$ till further use. Blood samples were collected from inferior vena cava of the control and treated animals, allowed to clot overnight at $4{ }^{\circ} \mathrm{C}$ and centrifuged for $20 \mathrm{~min}$ at $2000 \mathrm{~g}$. Serum was removed and stored at $-20^{\circ} \mathrm{C}$.

\section{Detection of Serum Iron Levels}

In serum samples from treated and control rats, iron levels were detected by colorimetric ferrozine-based assay. ${ }^{34}$ Briefly, the iron bound to Tf was released in an acidic medium as ferric iron and was then reduced to ferrous iron in the presence of ascorbic acid. Ferrous iron forms a blue complex with ferrozine.

\section{Enzyme-Linked Immunosorbent Assay}

For detection of cytokines and pro-Hepc in serum, we used Quantikine ${ }^{\circledR}$ IL-6, IL- $1 \beta$, TNF- $\alpha$ and IFN- $\gamma$ ELISA kits from R\&D systems and pro-Hepc from DRG International (Marburg, Germany). Samples were processed according to the manufacturer's instructions. Samples contained serum from TO-treated rats at different time points mentioned above after the TO injection.

\section{RNA Isolation}

Total RNA was isolated from different tissue samples by means of guanidine isothiocyanate extraction, cesium chloride density-gradient ultracentrifugation and ethanol precipitation according to the method described previously ${ }^{35}$ with some modifications as described elsewhere. ${ }^{36}$ The RNA obtained was quantified by measuring the absorbance at $260 \mathrm{~nm}$.

\section{Quantitative Real-Time PCR}

The cDNA was generated by reverse transcription of $1 \mu \mathrm{g}$ of total RNA with $100 \mathrm{nM}$ of dNTPs, $50 \mathrm{pM}$ of primer oligo $(\mathrm{dT})_{15}, 200 \mathrm{U}$ of moloney murine leukemia virus reverse transcriptase (M-MLV RT), $16 \mathrm{U}$ of protector RNase inhibitor, $1 \times$ RT buffer and $2.5 \mu \mathrm{l}$ of $0.1 \mathrm{M}$ DTT for $1 \mathrm{~h}$ at $40^{\circ} \mathrm{C}$. Gene expression was analyzed using Platinum Sybr Green qPCR mix UDG. GAPDH and $\beta$-actin were used as housekeeping genes. Primer sequences used are given in Table 1a.

The amplification was performed at $95-60^{\circ} \mathrm{C}$ for 45 cycles in an ABI prism 7000 sequence detection system. All samples were assayed in duplicate. The results were normalized to the housekeeping gene and fold change expression was calculated using threshold cycle $\left(C_{\mathrm{t}}\right)$ values.

\section{Northern Blot Analysis}

Total RNA (5-10 $\mu \mathrm{g} / \mathrm{lane})$ was size-fractionated by electrophoresis in $1 \%$ agarose-formaldehyde gels, transferred to nylon membranes using the capillary transfer systems and crosslinked by ultraviolet light. Rat Hepc, Hjv, Fpn1, IL-6 and IL- $1 \beta$ cDNAs were generated by PCR from rat hepatic RNA using specific primers (Table $1 \mathrm{~b}$ ). Hybridization was performed at $68^{\circ} \mathrm{C}$ for $2 \mathrm{~h}$ with random-primed $\alpha^{-32} \mathrm{P}$-labelled cDNA probes for Hepc, Hjv and Fpn1. 28SrRNA was used to confirm equal loading of the samples. An overnight incubation at $42^{\circ} \mathrm{C}$ for $28 \mathrm{~S}$ rRNA $5^{\prime}$-AAC GAT CAG AGT AGT TGG TAT TTC ACC- $3^{\prime 5}$ was performed.

\section{Preparation of Liver Homogenate and Measurement of Iron Concentration}

About $100 \mathrm{mg}$ of frozen tissue was homogenized with an Ultra-turrax TP 18/10 three times for $10 \mathrm{~s}$ each in 10 volumes of $50 \mathrm{mM}$ Tris- $\mathrm{HCl}$ buffer, $\mathrm{pH} 7.4$, containing $150 \mathrm{mM}$ sodium chloride, $1 \mathrm{mM}$ ethylenediaminetetraacetic acid, $1 \%$ Triton X-100, $1 \mathrm{mM}$ phenylmethanesulfonyl fluoride, $1 \mathrm{mM}$ benzamidine, $1 \mathrm{mg} / \mathrm{ml}$ leupeptin, $10 \mathrm{mM}$ chymostatin, $1 \mathrm{mg} /$ $\mathrm{ml}$ antipain and $1 \mathrm{mg} / \mathrm{ml}$ pepstatin A. The entire procedure was carried out at $4^{\circ} \mathrm{C}$. Crude homogenates were passed five times through a $22 \mathrm{G}$ needle applied to a syringe, centrifuged for $5 \mathrm{~min}$ at $10000 \mathrm{~g}$ and $4^{\circ} \mathrm{C}$, and the protein concentration was determined in supernatants using the BCA protein assay reagent kit (Pierce, Bonn, Germany). Aliquots of the homogenates were stored at $-20^{\circ} \mathrm{C}$ until use. Tissue homogenates were used to measure the iron levels by colorimetric ferrozine-based assay. ${ }^{34}$

\section{Prussian Blue Iron Staining}

Slides were stained with Accustain ${ }^{\circledR}$ Iron stain from SigmaAldrich using the protocol provided by the manufacturer. Briefly, the slides were deparaffinized and tissues were hydrated to deionized water. Slides were placed in working iron stain solution for $10 \mathrm{~min}$ followed by rinsing in deionized water. Slides were subsequently stained with working pararosaniline solution for 3-5 min and rinsed in deionized water followed by a rapid dehydration through alcohol and xylene.

\section{Statistical Analysis}

The data were analyzed using Prism Graph pad 4 software (San Diego, USA). All experimental errors are shown as s.e.m. Statistical significance was calculated by Student's $t$-test and one-way ANOVA and Dunnett post hoc test. Significance was accepted at $P<0.05$. 
Table 1 Summary of the primer sequences used in the study

\begin{tabular}{|c|c|c|}
\hline Primer & Forward $5^{\prime}-\ldots-\_-1--3^{\prime}$ & Reverse $5^{\prime}$ ———————- $3^{\prime}$ \\
\hline \multicolumn{3}{|c|}{ (a) Primer sequences used for real-time $P C R$ analysis } \\
\hline Ferritin-H & GCC CTG AAG AAC TाT GCC AAA T & TGC AGG AAG ATT CGT CCA CCT \\
\hline Fpn1 & TTC CGC ACT Tा CGA GAT GG & TAC AGT CGA AGC CCA GGA CTG T \\
\hline Dcytb & TCC TGA GAG CGA TTG TGT TG & TTA ATG GGG CAT AGC CAG AG \\
\hline Hjv & ATG CCG TGT CCA AGG AGC TT & TCC ACC TCA GCC TGG TAG AC \\
\hline HFE & ATC AGC CTC TCA CTG CCA CT & CAA GTG TGT CCC CTC CAA GT \\
\hline Hephaestin & CAC ATT ПT CCA GCC ACC ПT & TGA CGA ACT TTG CCT GTG AG \\
\hline Transferrin & GGC ATC AGA CTC CAG CAT CA & GCA GGC CCA TAG GGA TGT T \\
\hline IRP2 & CTG CAT CCC AGC CTA TTG AAA A & GCA CTG CTC CTA GCA ATG CTT C \\
\hline IL-6 & GTC AAC TCC ATC TGC CCT TCA G & GGC AGT GGC TGT CAA CAA CAT \\
\hline IL-1 $\beta$ & TAC CTA TGT CTT GCC CGT GGA G & ATC ATC CCA CGA GTC ACA GAG G \\
\hline TNF- $\alpha$ & ACA AGG CTG CCC CGA CTA T- & CTC CTG GTA TGA AGT GGC AAA TC \\
\hline $\mathrm{IFN}-\gamma$ & AGT CTG AAG AAC TAT TIT AAC TCA AGT AGC AT & CTG GCT CTC AAG TAT TIT CGT GTT AC \\
\hline GAPDH & TCC TGC ACC ACC AAC TGC TTA G & TाC TGA GTG GCA GTG ATG GCA \\
\hline$\beta$-Actin & TGT CAC CAA CTG GGA CGA TA & AAC ACA GCC TGG ATG GCT AC \\
\hline
\end{tabular}

\section{RESULTS}

\section{Changes in the Iron Levels in Serum and Liver Tissue}

An early decrease in serum iron levels was found after TO injection. This decline was highly significant at the later time points by Student's $t$-test $(P<0.001)$ and during the course of the study by one-way ANOVA $\left(P=8 \times 10^{-4}\right)$. In contrast, in the liver tissue, an increase in the iron content was observed. This increase became statistically significant at 12 and $24 \mathrm{~h}$ after TO administration (Figure 1a). Serum pro-Hepc concentration was not significantly changed in response to TO injection (Figure 1b).

\section{Serum Levels of Acute-Phase Cytokines}

A sharp increase in serum IL-6 concentration $(2018 \mathrm{pg} / \mathrm{ml})$ was detectable $2 \mathrm{~h}$ after TO injection, with maximum levels detected at $6 \mathrm{~h}$. IL- $1 \beta$ serum concentration also increased $(150 \mathrm{pg} / \mathrm{ml})$, but with lower order of magnitude (Figure 1c).
This increase of serum IL-6 was significant by both Student's $t$-test $(P<0.05)$ and ANOVA $(P=0.0013)$; however, the increase in IL- $1 \beta$ concentrations was significant only at later time points by Student's $t$-test but not with the ANOVA $(P=0.15)$, through the course of the study. Serum levels of TNF- $\alpha$ and IFN- $\gamma$ were also measured and a delayed but significant increase in serum IFN- $\gamma$ concentration was found by Student's $t$-test $(P<0.05)$ and by ANOVA $(P=0.02)$. On the other hand, the changes in the serum levels of TNF- $\alpha$ were not statistically significant (Figure 1d).

\section{Acute-Phase Cytokines Gene Expression in the Injured Muscle}

In the muscle, which is the site of injury, IL- 6 gene expression was significantly upregulated 3427 -fold $6 \mathrm{~h}$ after the onset of APR. At the same time, IL- $1 \beta$ gene expression was upregulated 400 -fold. IFN- $\gamma$ gene expression was significantly 

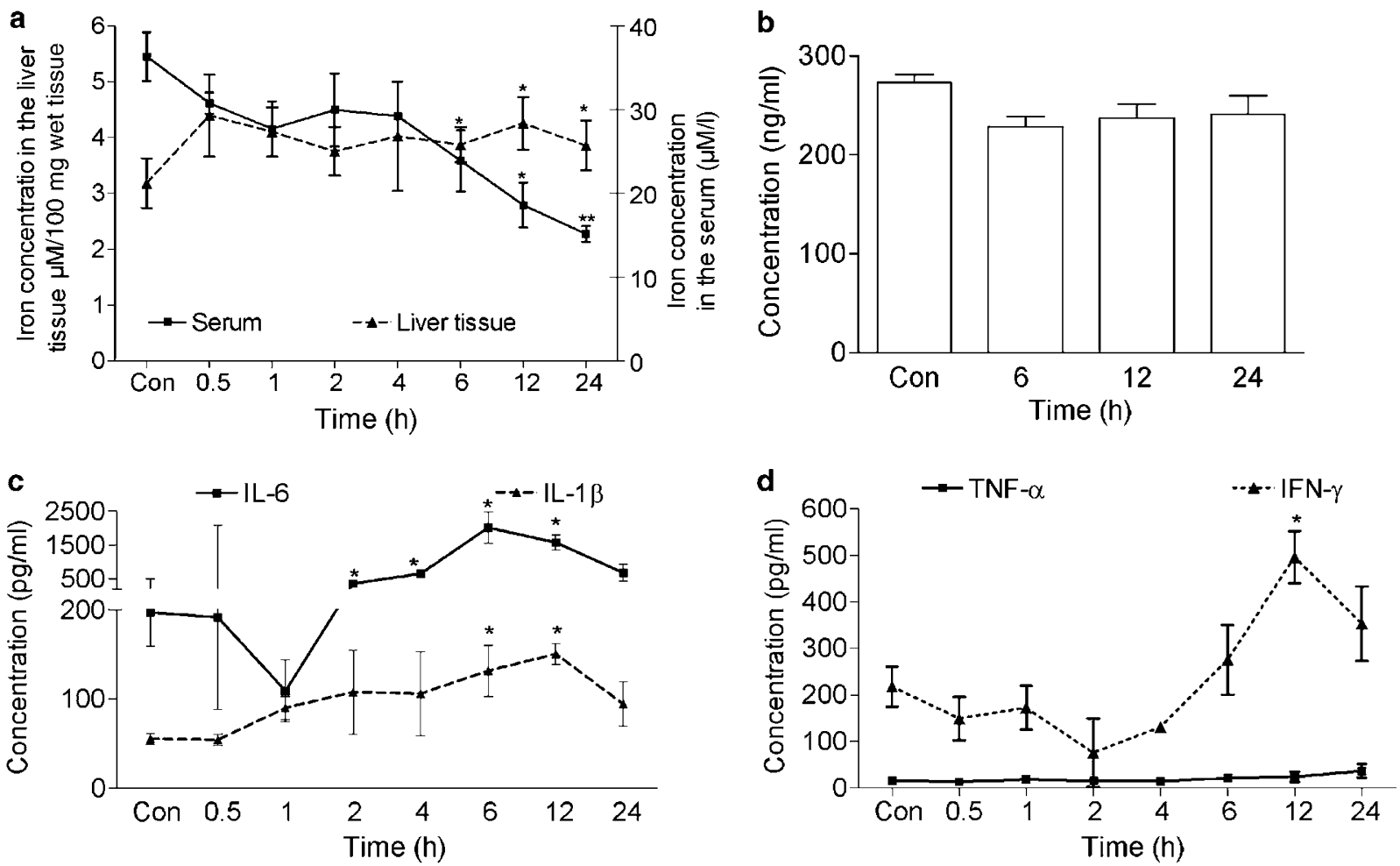

Figure 1 Changes in the iron level in the serum and liver tissue (a) pro-Hepc (b), IL- 6 and IL-1 $\beta$ (c) and TNF- $\alpha$ and IFN $\gamma$ (d). Serum iron levels were measured by routine clinical laboratory test using an iron ferrozine assay. Statistically significant decline in serum and increase in tissue iron level were found from 6 to $24 \mathrm{~h}$ after the TO injection (a). Pro-Hepc was measured using pro-Hepc ELISA and no significant changes in the pro-Hepc concentration were observed (b). Serum levels of acute-phase cytokines were measured using rat specific ELISAs as per the manufacturer's instruction. Statistically significant increases in serum IL- 6 and IL 1- $\beta$ concentrations were found with a maximum by $6 \mathrm{~h}$ of TO injection (c); however, a significant increase in serum IFN- $\gamma$ concentration was delayed to $24 \mathrm{~h}(\mathbf{d})$. Results represent the mean value \pm s.e.m. $\left({ }^{\star} P<0.05\right.$, analyzed by Student's $t$-test; $\left.n=4\right)$.

upregulated 5.71-fold $(P<0.05$; Figure $2 \mathrm{a})$ at $4 \mathrm{~h}$ whereas TNF- $\alpha$ gene expression was not significantly changed. The strong upregulation of IL- 6 and IL- $1 \beta$ was confirmed by Northern blotting, and maximum expression was seen $6 \mathrm{~h}$ after TO injection (Figure 2b).

\section{Expression of Acute-Phase Cytokines and Iron Regulatory Genes in the Liver}

As revealed by real-time PCR analysis, gene expression of IL1- $\beta$ and TNF- $\alpha$ was significantly upregulated in the liver, reaching maximum increases of 3.24- and 3.83-fold, respectively (4-6h), whereas IL-6 gene expression was significantly downregulated at $6 \mathrm{~h}$ (Figure 2c); however, this decrease in IL-6 gene expression was not significant by ANOVA.

Hepc, ferritin-H-, DMT1 gene expression was significantly upregulated $(7 \pm 0.72-, 1.44 \pm 0.12-$ and $2.85 \pm 0.27$-fold: $P<0.05$, respectively) $6 \mathrm{~h}$ after the onset of the APR. The upregulation of DMT1-gene expression was not significant when analyzed by one-way ANOVA $(P=0.08$; Figure $3 \mathrm{a}$ and b). Tf gene expression was significantly upregulated at earlier time points, but later on the gene expression was significantly downregulated $(0.70 \pm 0.08$-fold: $P<0.05$; Figure $3 \mathrm{a})$; however, the changes were highly significant during the whole course of the study by one-way ANOVA $\left(P=2 \times 10^{-4}\right)$. Both TfR1 and TfR2 responsible for Tf-bound iron uptake gene expression were significantly upregulated. Early upregulation of TfR1 gene expression was observed (1.7 \pm 0.24 -fold; $P<0.05) 30 \mathrm{~min}$ after the TO injection; however, TfR2 upregulation was delayed $(1.76 \pm 0.03$-fold; $P<0.05)$ to $6 \mathrm{~h}$ (Figure 3b). IRP1- and IRP2- (1.7 \pm 0.084 - and $1.83 \pm 0.33$ fold; $P<0.01)$ gene expression was upregulated significantly (Figure 3d).

Hjv gene expression was significantly downregulated $(0.12 \pm 0.05$-fold; $P<0.001)$ at $6 \mathrm{~h}$ (Figure $3 \mathrm{c}$ ) while Fpn $1-$, Dcytb-, HFE- and Heph gene expression (0.30 $\pm 0.10-$, $0.30 \pm 0.07-, 0.18 \pm 0.03$ - and $0.27 \pm 0.03$-fold, respectively; $P<0.05$ ) was downregulated at $12 \mathrm{~h}$ (Figure $3 \mathrm{a}-\mathrm{c}$ ). The downregulation was highly significant when analyzed by oneway ANOVA $\left(P<5 \times 10^{-4}\right)$.

Northern blot analysis was performed to verify real-time PCR findings. The filters with RNA size fractionized by electrophoresis were hybridized with Hepc-, Hjv- and Fpn1specific cDNA probes and the intensity of the radioactive label was recorded on the autoradiographic films after incubating at $-80^{\circ} \mathrm{C}$. We found an increase in Hepc gene expression with a maximum expression at $6 \mathrm{~h}$ after the TO 

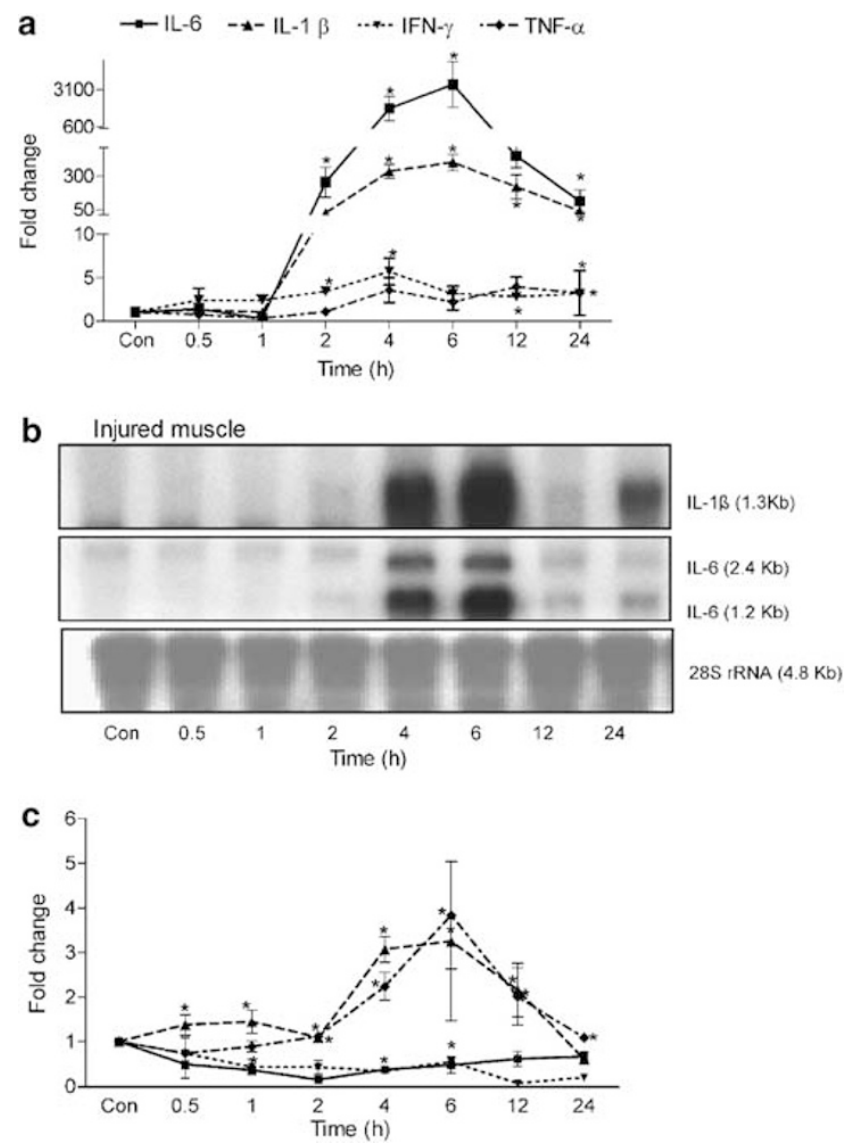

Figure 2 mRNA expression of acute-phase cytokines analyzed by real-time PCR (a) and Northern blotting (b) in the injured muscle and analyzed by real-time PCR (c) in the liver at different time points after intramuscular TO injection. IL- 6 and IL-1 $\beta$ mRNA was induced in the muscle $2 \mathrm{~h}$ after TO injection. The maximum expression of IL- 6 and IL-1 $\beta$ was found at $4-6 \mathrm{~h}$ in the injured muscle. Results represent mean value + s.e.m. $\left({ }^{\star} P<0.05\right.$, analyzed by Student's $t$-test; $n=4$ ).

injection; however, Hjv- and Fpn1 gene expression was downregulated at this time (Figure 3e).

\section{Expression of Iron Metabolism Genes in Extrahepatic Organs}

In addition to comparison of gene expression to a housekeeping gene in extrahepatic organs, the quantitative comparison of the gene expression was determined by comparing $C_{\mathrm{t}}$ values (see Supplementary Information). We not only found the expression but also the upregulation of Hepc gene in the extrahepatic organs. Statistical analysis showed that this expression was significantly changed in the extrahepatic organs $(P<0.05)$; however, in spleen, the changes in the gene expression were reproducible but did not reach statistical significance. Ferritin- $\mathrm{H}$ gene expression was significantly downregulated in different organs while in kidney an upregulation was found. Tf gene expression was variably regulated in the extrahepatic organs. A significant upregulation was observed in the small intestine. On the other hand, Tf gene expression was significantly downregulated in heart and kidney (Figures 4a-8a).

$D M T 1$ gene expression was significantly downregulated in small intestine, spleen and kidney. In colon, the upregulation of DMT1 gene expression was followed by a downregulation. $D c y t b$ gene expression was significantly increased in small the intestine $(P<0.005)$ and not in other organs under study. TfR1 gene expression was only significantly downregulated in spleen $(P=0.013)$ whereas the changes in other organs were not significant when analyzed by one-way ANOVA. TfR2 gene expression was significantly downregulated in the small intestine and spleen while in kidney an opposite regulation was observed (Figures $4 \mathrm{~b}-8 \mathrm{~b}$ ).

Heph gene expression was downregulated in extrahepatic organs; however, these changes were only significant in spleen through the whole course of study by ANOVA $(P=0.0042)$. $\mathrm{Hjv}$ gene expression was quite strong in heart as it was evident by $C_{\mathrm{t}}$ values (Supplementary Information); however, this upregulation was not significant. On the other hand, $\mathrm{Hjv}$ gene expression was significantly upregulated at $4 \mathrm{~h}$ in kidney followed by a significant downregulation $(P=0.007)$. HFE gene expression was significantly downregulated in heart and kidney; however, in other organs, the downregulation was not statistically significant (Figures $4 \mathrm{c}-8 \mathrm{c}$ ).

IRP1 gene expression was significantly upregulated in colon and kidney $(P<0.025)$. In heart, the upregulation of IRP1 gene expression was significant at early time points; however, it was significantly downregulated later when analyzed by Student's $t$-test. The changes in IRP1 gene expression were not significant through the course of experimental study when analyzed by ANOVA. IRP2 gene expression was significantly changed in the small intestine but not in any other organ under study when evaluated by ANOVA (Figures $4 d-8 d)$.

Fpn1 gene expression was significantly downregulated in heart, colon and spleen at $6 \mathrm{~h}$ as in the liver; however, in the small intestine and kidney, the downregulation was not significant. Detectability of Hepc, Hjv and Fpn1 mRNA expression by Northern blot analysis was somehow related to $C_{\mathrm{t}}$ values. In fact, Hepc and Hjv mRNA (with the exception of the heart) could not be detected by Northern blot analysis in extrahepatic organs because of the low abundance of the specific mRNA (high $C_{\mathrm{t}}$ values determined by real-time PCR). Fpn 1 mRNA on the contrary was easily detectable in different organs by Northern blot analysis (Figure 9).

\section{Prussian Blue Iron Staining}

Although the decrease of serum iron and the increase of liver iron concentrations were statistically significant, we were not able to show the increase of iron deposition in liver cells by Prussian blue iron staining (data not shown). It is likely that to detect an increase of iron concentration in the tissue by staining, the levels would have to increase to even higher levels. ${ }^{37}$ 

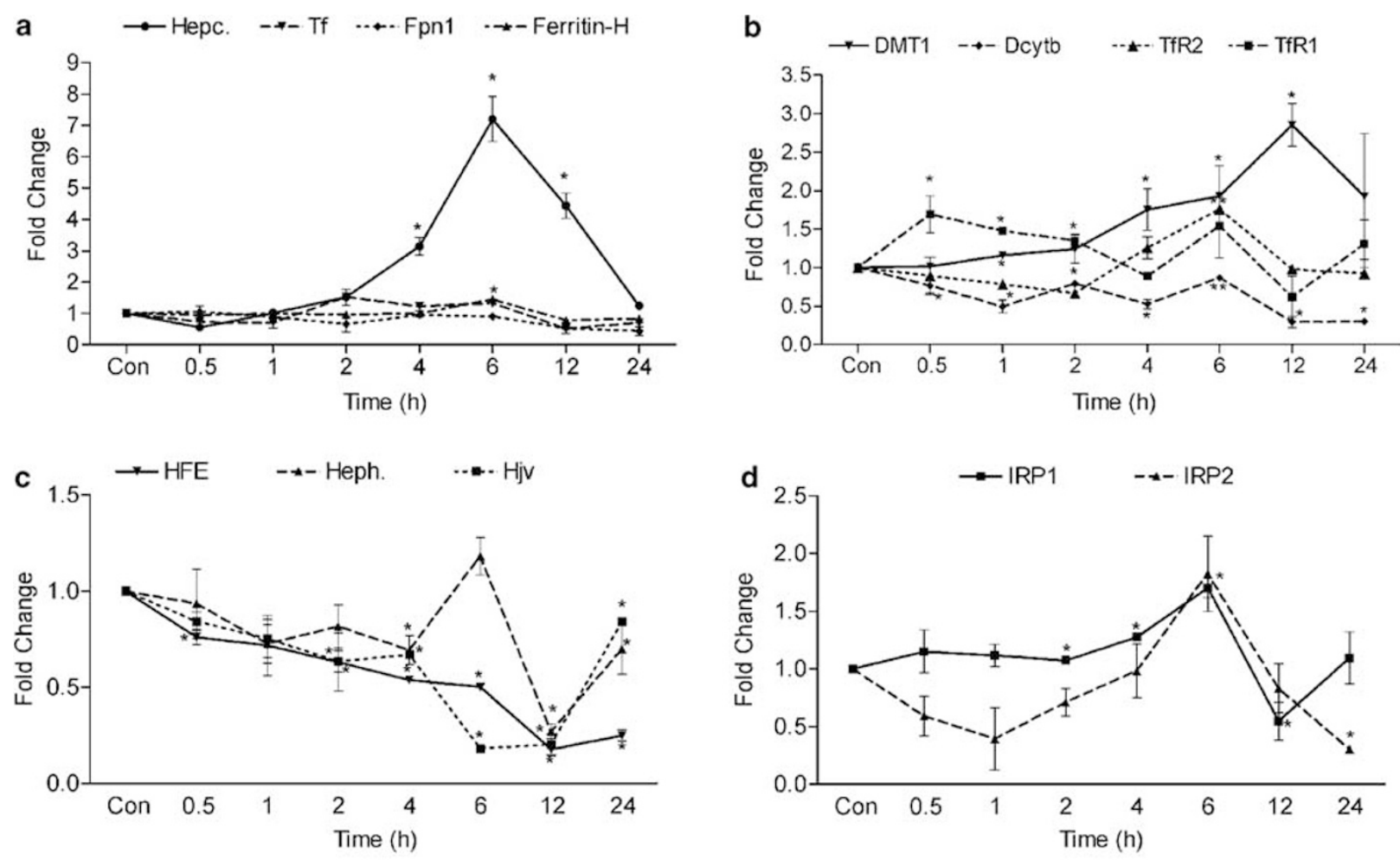

e Liver
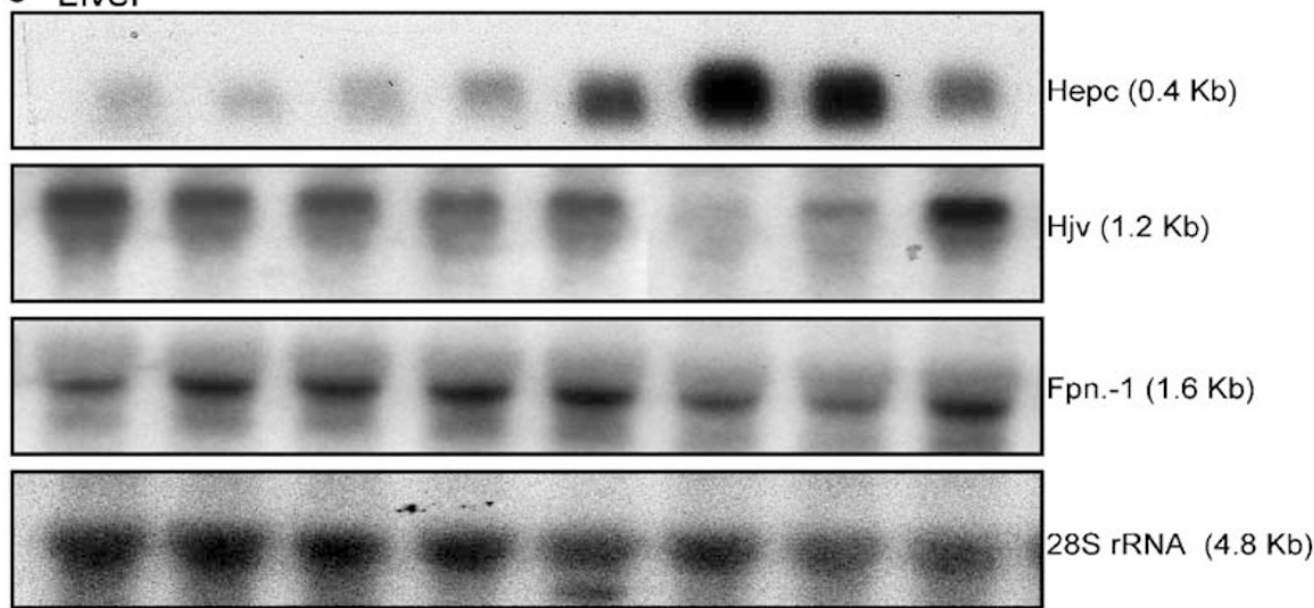
Con
0.5
1
$\begin{array}{ccc}2 & 4 & 6 \\ & \text { Time }(h)\end{array}$
12
24

Figure 3 mRNA expression of Hepc, Tf, Fpn1 and Ferritin-H (a), DMT1, Dcytb, TfR2 and TfR1 (b), HFE, Heph and Hjv (c) and IRP1 and IRP2 (d) in the liver of rats after administration of TO in the hind limb muscle. The animals were killed at given time points, RNA was isolated, reverse transcribed and subjected to real-time PCR as described in Materials and methods. Results represent mean value \pm s.e.m. $\left({ }^{*} P<0.05\right.$, analyzed by Student's $t$-test; $\left.n=4\right)$. Northern blot analysis of total RNA extracted from liver (e) Specific cDNA probes were radiolabelled with $\alpha_{-}{ }_{32}$ P-labelled deoxycytidine triphosphate (specific activity $3000 \mathrm{Ci} / \mathrm{mmol}$ ) for Hepc, Hjv- and Fpn1-specific RNA levels in the liver of TO-injected rats. Pictures show the results of one of four animals.

\section{DISCUSSION}

The liver is a central organ for iron metabolism, which involves regulation and expression of numerous proteins. In this paper, we studied the changes in expression of Hepc gene and of other genes induced in the liver and extrahepatic organs. An in vivo model of TO-induced APR in the rat was used to better appreciate the role of acute-phase mediators in regulating the iron metabolism genes in the liver and other organs. We found that Hepc gene is expressed not only in the liver but also extrahepatic organs. The APR-induced upregulation of Hepc could also be detected in the extrahepatic sites with similar kinetics as in the liver. This modulation could be owing to acute-phase mediators mainly IL-6 coming via bloodstream. 

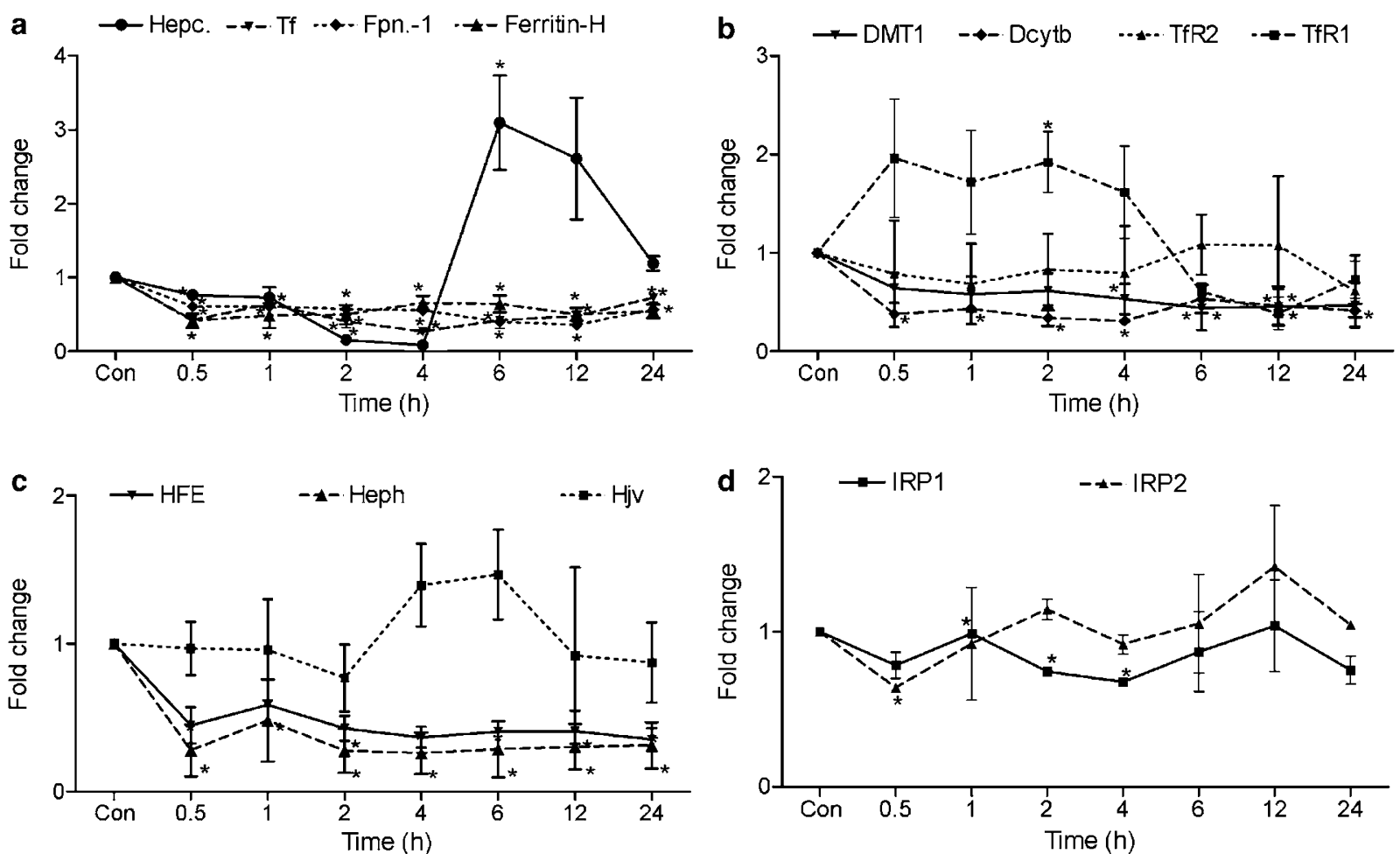

Figure 4 mRNA expression of Hepc, Tf, Fpn1 and Ferritin-H (a), DMT1, Dcytb, TfR2 and TfR1 (b), HFE, Heph and Hjv (c), and IRP1 and IRP2 (d) in the heart studied by real-time PCR as described in Materials and methods. Results represent the mean value \pm s.e.m. $\left({ }^{*} P<0.05\right.$, analyzed by Student's $t$-test; $\left.n=4\right)$.
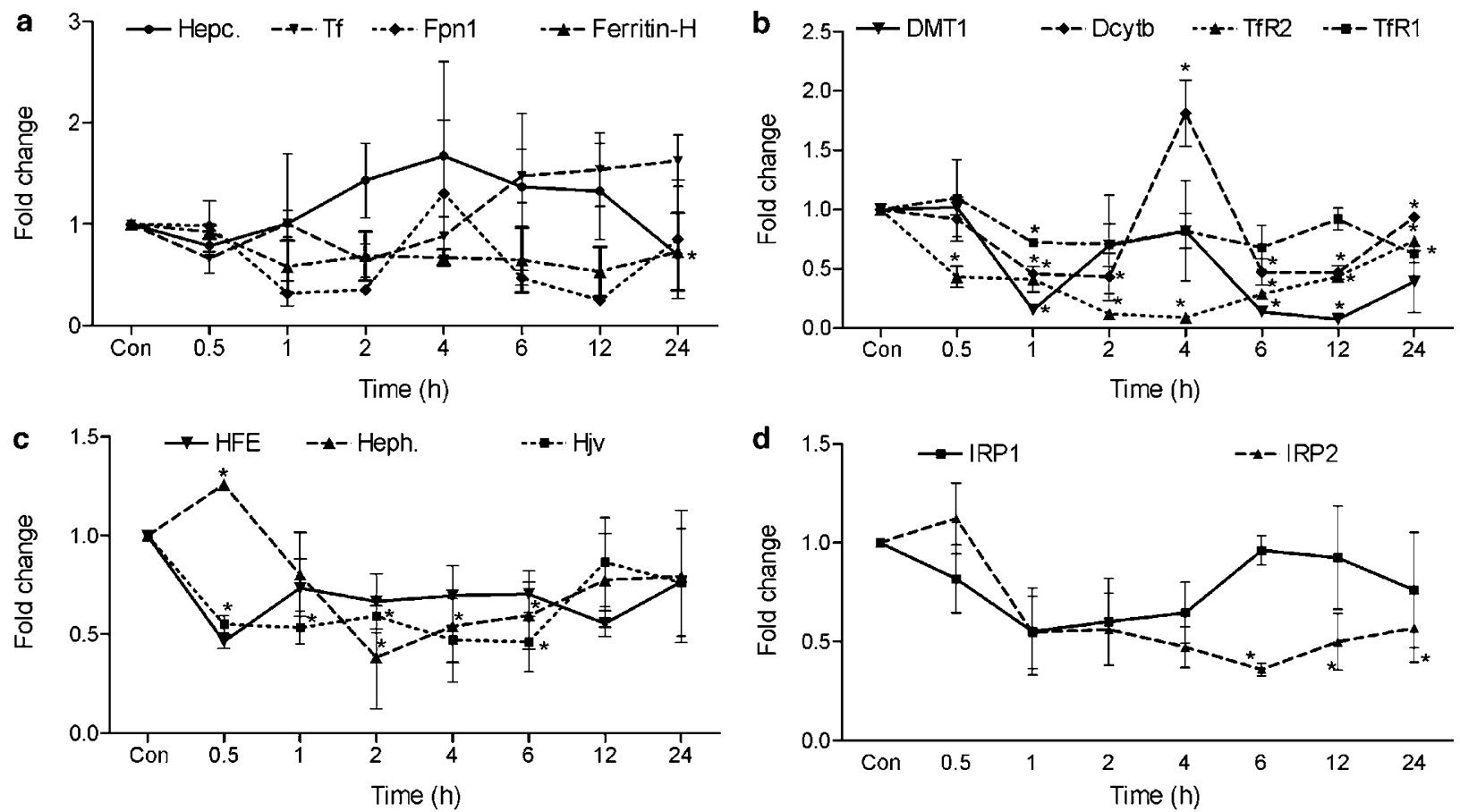

Figure 5 mRNA expression of Hepc, Tf, Fpn1 and Ferritin-H (a), DMT1, Dcytb, TfR2 and TfR1 (b), HFE, Heph and Hjv (c), and IRP1 and IRP2 (d) in the small intestine studied by real-time PCR. Results represent the mean value \pm s.e.m. $\left({ }^{*} P<0.05\right.$, analyzed by Student's $t$-test; $\left.n=4\right)$.

Serum levels of IL-6 and IL-1 $\beta$ were strongly upregulated; the level of IL- 6 was, at its maximum, nine times higher than that of IL-1 $\beta$. However, while IL-6 gene expression was dramatically upregulated in the injured muscle, it was downregulated in the liver. In contrast, in one model of LPSinduced inflammation, upregulation of IL-6 gene expression 

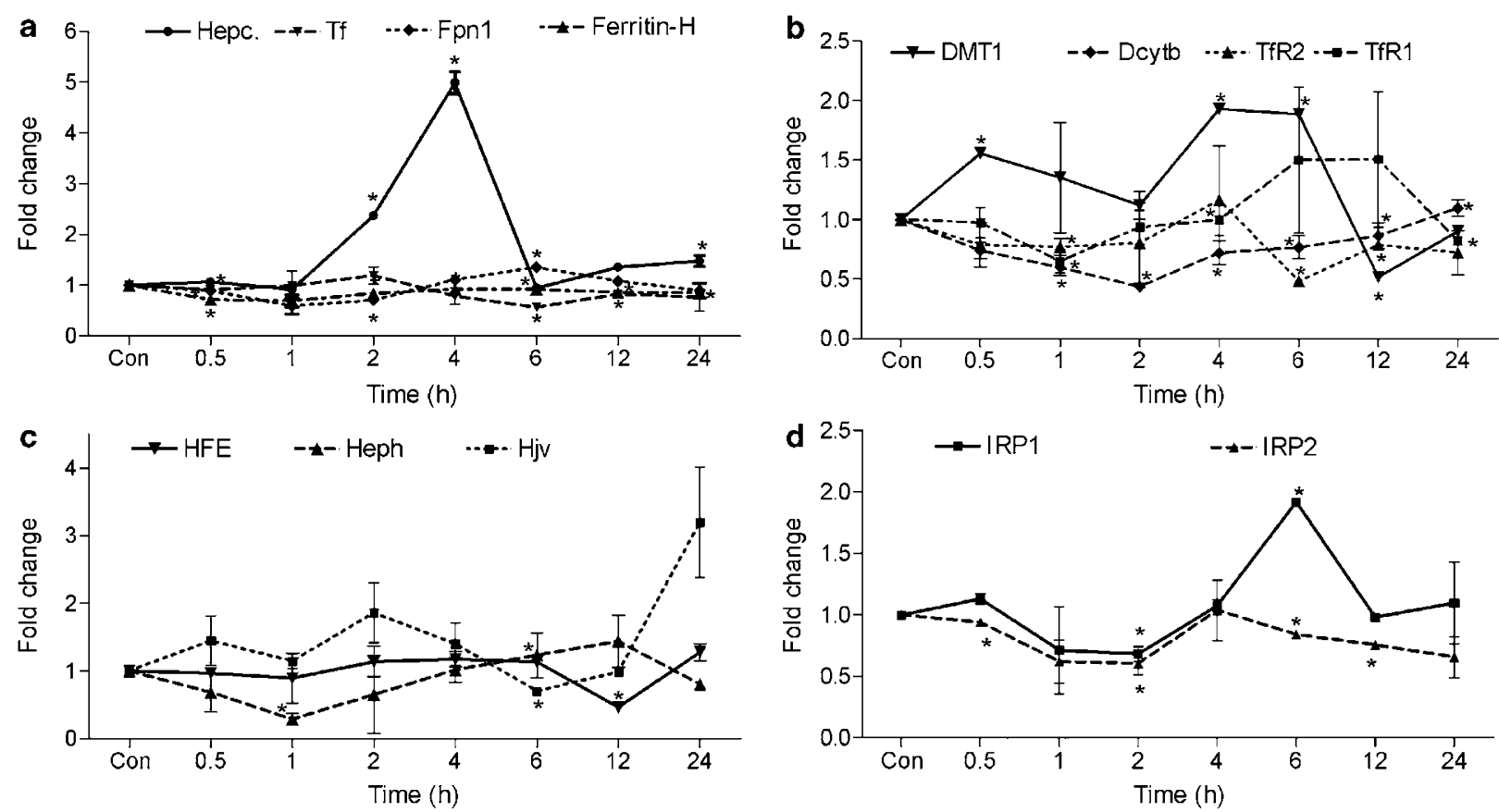

Figure 6 Real-time PCR analysis of mRNA expression of Hepc, Tf, Fpn1 and Ferritin-H (a), DMT1, Dcytb, TfR2 and TfR1 (b), HFE, Heph and Hjv (c), and IRP1 and IRP2 (d) in the colon. Results represent the mean value \pm s.e.m. $\left({ }^{*} P<0.05\right.$, analyzed by Student's $t$-test; $\left.n=4\right)$.
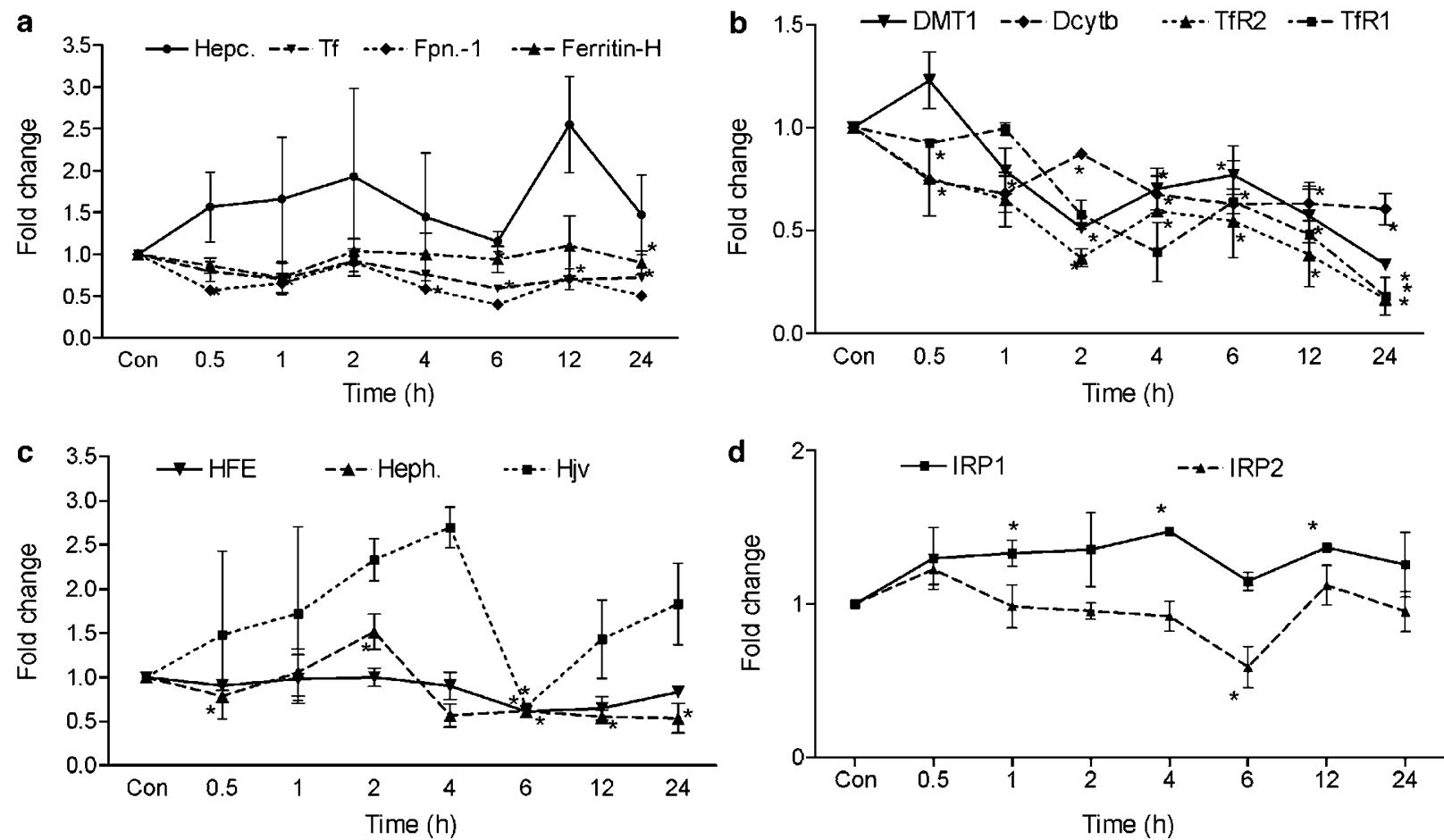

Figure 7 Real-time PCR analysis of expression of Hepc, Tf, Fpn1 and Ferritin-H (a), DMT1, Dcytb, TfR2 and TfR1 (b), HFE, Heph and Hjv (c), and IRP1 and IRP2 (d) mRNA in the spleen. TfR 1 gene expression was significantly changed in spleen only. Results represent the mean value \pm s.e.m. $\left({ }^{*} P<0.05\right.$, analyzed by Student's $t$-test; $n=4$ ).

has been reported in the liver. ${ }^{38}$ Injected LPS is mainly taken up by the Kupffer cells and is responsible for the upregulation of IL-6 in the liver. On the other hand, TO-induced local irritation is a model of inflammation, which results in the recruitment of inflammatory cells and the upregulation of IL-6 in the injured muscle. ${ }^{7}$ This study underlines the 

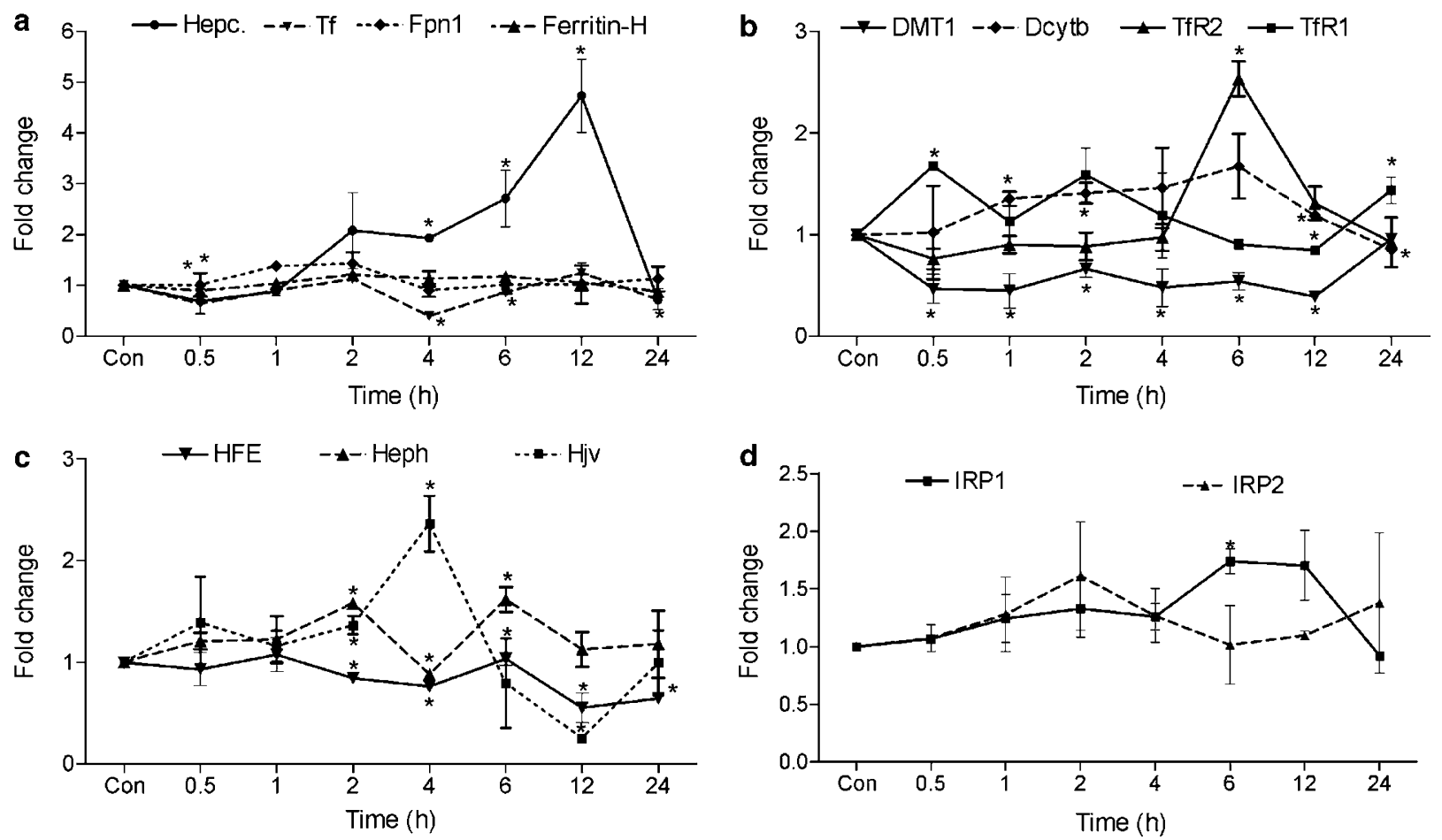

Figure 8 mRNA expression of Hepc, Tf, Fpn1 and Ferritin-H (a), DMT1, Dcytb, TfR2 and TfR1 (b), HFE, Heph and Hjv (c), and IRP1 and IRP2 (d) in the kidney. Results represent the mean value \pm s.e.m. $\left({ }^{*} P<0.05\right.$, analyzed by Student's $t$-test; $\left.n=4\right)$.

Fpn.-1
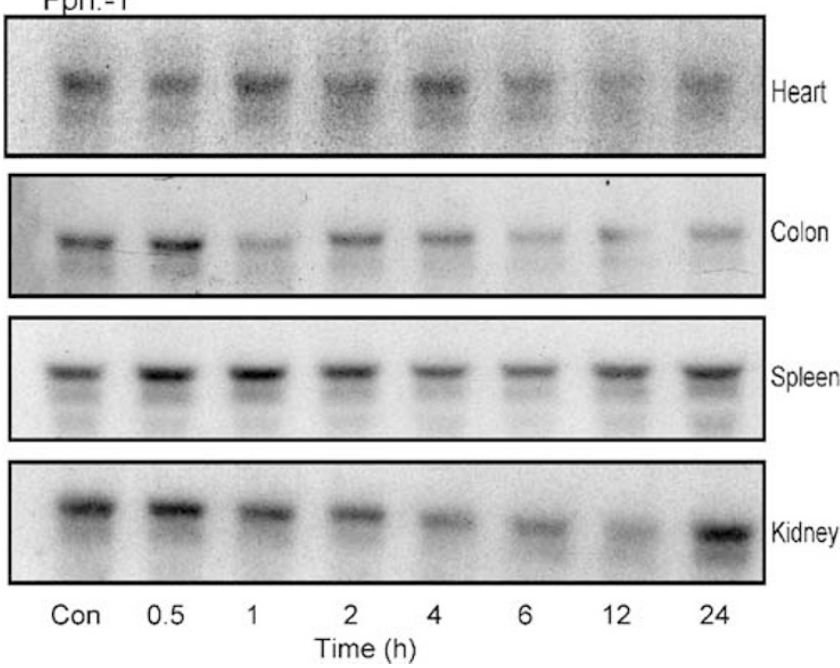

28S rRNA
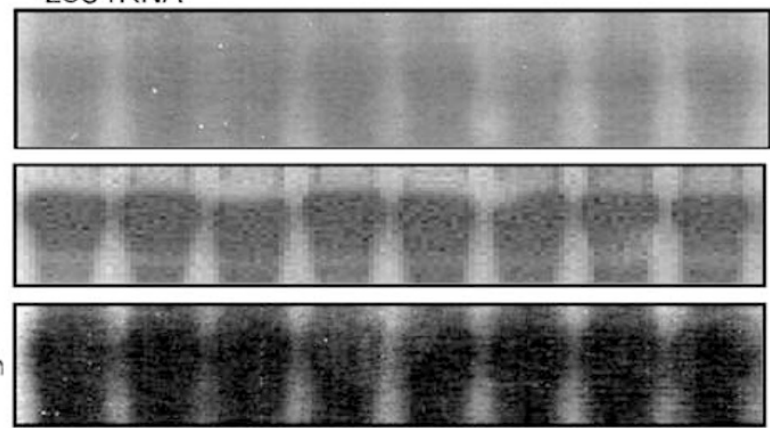

Kidney

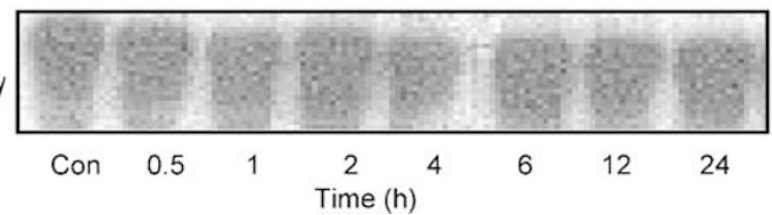

Figure 9 Northern blot analysis of total RNA extracted from different organs of the TO-injected rats taken at different time points (Materials and methods). Fpn1-specific cDNA probes radiolabelled with $\alpha_{-32}$ P-labelled deoxycytidine triphosphate (specific activity $3000 \mathrm{Ci} / \mathrm{mmol}$ ) were used for hybridization. Fpn1-mRNA-expression could be demonstrated in all the organs with a similar pattern of regulation, that is, Fpn1 mRNA expression was downregulated during TO-induced APR.

differences between the two animal models and indirectly confirms that IL-6 is the major player in modifying iron metabolism under acute-phase condition. ${ }^{13,38-44}$

Most studies to date have shown that the transcriptional changes in the Hepc gene expression parallel the changes in serum iron concentration; however, limited studies have been performed to show the changes in the concentration of this important hormone in the serum. ${ }^{45-48}$ Intramuscular TO injection induced significant decrease of the serum iron concentration without a significant change in serum proHepc concentration. One possible explanation for no significant change in serum concentration of Hepc could be that 
the upregulation of gene expression in the liver although significant is not enough (seven-fold) to induce measurable changes in the serum level. It is possible that a measurable change in serum concentration is only possible if the transcriptional changes are large enough. In the sera of $\gamma$-irradiated rats, significant upregulation of pro-Hepc serum level was associated with 30-fold upregulation of hepatic Hepc gene expression. ${ }^{39}$ Similarly, the serum level of CINC-1 increased 15-fold, when the hepatic expression of CINC-1 was upregulated 260-fold during APR. ${ }^{7}$ Also, the ELISA used to measure the serum Hepc concentration was not specific for biologically active Hepc- $25 .^{30,49}$ No practical assay has been reported for measurement of active Hepc-25, although attempts have been made to develop an assay system by using SELDI-TOF MS. ${ }^{50}$

Hjv gene expression could be confirmed in skeletal muscle, heart and liver; ${ }^{51}$ however, Hjv gene expression was clearly detectable in kidney and in smaller amounts in extrahepatic organs where it was downregulated. In non-HFE-HH, Hepc gene expression was reduced, ${ }^{51,52}$ which suggests that $\mathrm{Hjv}$ could be involved in Hepc regulation; however, the mechanism is still unclear.

In mammals, iron bioavailability is regulated at three principal sites: duodenal uptake, release from hepatic stores and recycling of scavenged iron from senescent red blood cells via reticuloendothelial macrophages. ${ }^{53}$ During APR, iron concentration in the blood was decreased to a significantly low level by $24 \mathrm{~h}$ of TO injection. At the same time, the liver iron contents were significantly increased by $33 \%$, demonstrating that the iron status in serum and liver, the most important organ in iron metabolism, is affected during APR. Prussian blue staining however was not sensitive enough to detect the increased hepatic iron concentration. A significant overload of iron has been reported in liver samples from Smad4 ${ }^{\mathrm{Co} / \mathrm{Co}} \mathrm{Alb}$-Cre mutant mice. Prussian blue staining showed that beginning at the age of 2 months, iron accumulated in the liver with pigmentation. Quantitative measurement showed a nine-fold increase in iron concentrations in the liver samples and confirmed alteration of iron levels in these organs. ${ }^{37}$

Fpn1 gene expression was downregulated in liver and in extrahepatic organs. These changes in gene expression were parallel to the significant decline in serum iron levels. The signal for downregulation of Fpn1 could be initiated as a consequence of Hepc-Fpn1 interaction. ${ }^{22,28,29}$ Heph in association with Fpn1 plays an important role in iron transfer across the basolateral membrane into the serum. ${ }^{25} \mathrm{~A}$ significant downregulation of Heph during APR supports the hypothesis that it could be involved in the export of iron across the basolateral membrane.

DMT1 gene expression was upregulated in the liver whereas Dcytb gene expression was significantly downregulated. DMT1 and Dcytb interact to take up iron; however, how these two components of the iron uptake machinery are regulated is still unknown. Iron concentration has strong effects on expression of these two proteins. In case of blood loss, decrease in serum iron concentration acts as a signal to increase the uptake of dietary iron in the intestine; consequently, the DMT1- and Dcytb gene expression is upregulated. $^{22,54}$

Early upregulation followed by downregulation of Tf gene expression was found in the liver. Gene expression of TfR1 and TfR2, responsible for iron uptake from diferric Tf via receptor-mediated endocytosis, ${ }^{55}$ were upregulated. Tf gene expression was significantly downregulated in heart and kidney. Crosstalk between different signalling pathways like IL-6, HFE, Hjv and TfR2 results in the variable regulation of Hepc during inflammation or altered iron conditions. ${ }^{38}$

Hepatic HFE forms a complex with TfR $1 .{ }^{18}$ The binding sites of HFE and diferric Tf overlap. ${ }^{56}$ HFE along with diferric-Tf-TfR1 complex is endocytosed during receptormediated endocytosis. ${ }^{57}$ Despite iron overload, patients with HFE mutations and HFE-deficient mice show hepatic HepcmRNA levels below those of normal control mice, suggesting that HFE is required for Hepc gene expression; ${ }^{58,59}$ however, Hepc gene expression was not completely abolished in HFEdeficient mice, indicating the existence of intact Hepc regulatory setup ${ }^{60}$ in the absence of HFE. Our findings suggest an inverse relationship between Hepc- and HFE gene expression in the liver and extrahepatic organs during TOinduced APR.

IRPs are critical determinants of the post-transcriptional regulation of TfR expression. Besides ferritin and TfR1, DMT1 and Fpn1 mRNA contain IRE-like sequences, suggesting that IRP might possibly affect the use of these mRNAs. $^{24,27,61}$ DMT1 expression is regulated by iron in some but not all situations ${ }^{62-64}$ whereas Fpn1 mRNA abundance responds to alterations in iron status. ${ }^{27}$ Iron regulates the synthesis of ferritin and TfRs, ${ }^{65}$ and IRPs indirectly modulate TfR mRNA translation by influencing its rate of degradation. When IRPs bind to TfR mRNA, they retard its degradation, and mRNA has a half-life of $6 \mathrm{~h}$. When IRPs are not bound to the mRNA, it has a much shorter half-life $(<1 \mathrm{~h}) .{ }^{66}$ However, TfR2 is encoded by an mRNA that lacks IREs, which indicates that in some circumstances regulation of the number of Tf-binding sites in the cell would not be controlled by IRP. ${ }^{67}$ In contrast, expression of TfR2 appears to be refractory to alterations in iron status, at least in liver. ${ }^{68}$

From these findings, we conclude that Hepc gene expression is upregulated during TO-induced APR not only in the liver but also in the systemic organs. This hormone can regulate or at least influence the expression of different proteins like Fpn1, DMT1 and other iron regulatory proteins studied during the APR. IL- 6 (along with IL-1 $\beta$ ) produced at the site of injury could be the main mediator of the changes observed in the liver and in the other organs as well. Furthermore, the finding that most of the known genes of iron metabolism are expressed in both the liver and in the extrahepatic organs suggests that extrahepatic organs may 
participate in regulating the serum iron level and systemic iron metabolism.

Supplementary Information accompanies the paper on the Laboratory Investigation website (http://www.laboratoryinvestigation.org)

\section{ACKNOWLEDGEMENTS}

We thank Mrs Renate Klages, Anke Herbst, Christin Hoffmann and Sylvia Bierkamp for their kind and skillful technical assistance. This work was supported by grants from the 'Deutsche Forschungsgemeinschaft' SFB 402 TP C6, C7, D3 and GRK 335.

1. Lieu PT, Heiskala M, Peterson PA, et al. The roles of iron in health and disease. Mol Aspects Med 2001;22:1-87.

2. Frazer DM, Wilkins SJ, Becker EM, et al. A rapid decrease in the expression of DMT1 and Dcytb but not Ireg1 or hephaestin explains the mucosal block phenomenon of iron absorption. Gut 2003;52:340-346.

3. Weiss G. Modification of iron regulation by the inflammatory response. Best Pract Res Clin Haematol 2005;18:183-201.

4. Roy CN, Custodio AO, de GJ, et al. An Hfe-dependent pathway mediates hyposideremia in response to lipopolysaccharide-induced inflammation in mice. Nat Genet 2004;36:481-485.

5. Ramadori G, Sipe JD, Colten HR. Expression and regulation of the murine serum amyloid A (SAA) gene in extrahepatic sites. J Immunol 1985;135:3645-3647.

6. Gruys $E$, Toussaint MJ, Niewold TA, et al. Acute phase reaction and acute phase proteins. J Zhejiang Univ Sci B 6;2005:1045-1056.

7. Sheikh N, Tron K, Dudas J, et al. Cytokine-induced neutrophil chemoattractant- 1 is released by the noninjured liver in a rat acute-phase model. Lab Invest 2006;86:800-814.

8. Ramadori G, Christ B. Cytokines and the hepatic acute-phase response. Semin Liver Dis 1999;19:141-155.

9. Krause A, Neitz S, Magert HJ, et al. LEAP-1, a novel highly disulfide-bonded human peptide, exhibits antimicrobial activity. FEBS Lett 2000;480:147-150.

10. McGrath Jr H, Rigby PG. Hepcidin: inflammation's iron curtain. Rheumatology 2004;43:1323-1325.

11. Means RT. Hepcidin and cytokines in anaemia. Hematology 2004:9:357-362.

12. Lipinski P, Starzynski RR. Regulation of body iron homeostasis by hepcidin. Postepy Hig Med Dosw (Online) 2004;58:65-73.

13. Deicher R, Horl WH. New insights into the regulation of iron homeostasis. Eur J Clin Invest 2006;36:301-309.

14. Ganz T. Hepcidin in iron metabolism. Curr Opin Hematol 2004;11: 251-254.

15. Nicolas G, Bennoun M, Devaux I, et al. Lack of hepcidin gene expression and severe tissue iron overload in upstream stimulatory factor 2 (USF2) knockout mice. Proc Natl Acad Sci USA 2001;98: 8780-8785.

16. Balogh A, Derzbach L, Vasarhelyi B. Hepcidin, the negative regulator of iron absorbtion. Orv Hetil 2004;145:1549-1552.

17. Anderson GJ, Frazer DM, Wilkins SJ, et al. Relationship between intestinal iron-transporter expression, hepatic hepcidin levels and the control of iron absorption. Biochem Soc Trans 2002;30:724-726.

18. Waheed A, Parkkila S, Zhou XY, et al. Hereditary hemochromatosis: effects of $\mathrm{C} 282 \mathrm{Y}$ and $\mathrm{H} 63 \mathrm{D}$ mutations on association with beta 2-microglobulin, intracellular processing, and cell surface expression of the HFE protein in COS-7 cells. Proc Natl Acad Sci USA 1997;94:12384-12389.

19. Gross CN, Irrinki A, Feder JN, et al. Co-trafficking of HFE, a nonclassical major histocompatibility complex class I protein, with the transferrin receptor implies a role in intracellular iron regulation. J Biol Chem 1998;273:22068-22074.

20. Fleming RE, Ahmann JR, Migas MC, et al. Targeted mutagenesis of the murine transferrin receptor-2 gene produces hemochromatosis. Proc Natl Acad Sci USA 2002;99:10653-10658.

21. Niederkofler V, Salie R, Arber S. Hemojuvelin is essential for dietary iron sensing, and its mutation leads to severe iron overload. J Clin Invest 2005;115:2180-2186.
22. Frazer DM, Anderson GJ. Iron imports. I. Intestinal iron absorption and its regulation. Am J Physiol Gastrointest Liver Physiol 2005;289:G631-G635.

23. McKie AT, Barrow D, Latunde-Dada GO, et al. An iron-regulated ferric reductase associated with the absorption of dietary iron. Science 2001;291:1755-1759.

24. Gunshin H, Mackenzie B, Berger UV, et al. Cloning and characterization of a mammalian proton-coupled metal-ion transporter. Nature 1997;388:482-488.

25. Vulpe CD, Kuo YM, Murphy TL, et al. Hephaestin, a ceruloplasmin homologue implicated in intestinal iron transport, is defective in the sla mouse. Nat Genet 1999;21:195-199.

26. Canonne-Hergaux F, Donovan A, Delaby C, et al. Comparative studies of duodenal and macrophage ferroportin proteins. Am J Physiol Gastrointest Liver Physiol 2006;290:6156-6163.

27. McKie AT, Marciani P, Rolfs A, et al. A novel duodenal iron-regulated transporter, IREG1, implicated in the basolateral transfer of iron to the circulation. Mol Cell 2000;5:299-309.

28. Fleming RE, Bacon BR. Orchestration of iron homeostasis. N Engl J Med 2005:352:1741-1744.

29. Nemeth E, Tuttle MS, Powelson J, et al. Hepcidin regulates cellular iron efflux by binding to ferroportin and inducing its internalization. Science 2004;306:2090-2093.

30. Sheikh N, Batusic DS, Dudas J, et al. Hepcidin and hemojuvelin gene expression in rat liver damage: in vivo and in vitro studies. Am J Physiol Gastrointest Liver Physiol 2006;291:G482-G490.

31. Mehlhase J, Gieche J, Widmer $\mathrm{R}$, et al. Ferritin levels in microglia depend upon activation: modulation by reactive oxygen species. Biochim Biophys Acta (BBA)—Mol Cell Res 2006;1763: 854-859.

32. Gray NK, Hentze MW. Iron regulatory protein prevents binding of the $43 \mathrm{~S}$ translation pre-initiation complex to ferritin and eALAS mRNAs. EMBO J 1994:13:3882-3891.

33. Tacchini L, Fusar PD, Bernelli-Zazzera A, et al. Transferrin receptor gene expression and transferrin-bound iron uptake are increased during postischemic rat liver reperfusion. Hepatology 2002;36: 103-111.

34. Riemer J, Hoepken HH, Czerwinska H, et al. Colorimetric ferrozine-based assay for the quantitation of iron in cultured cells. Anal Biochem 2004;331:370-375.

35. Chirgwin JM, Przybyla AE, MacDonald RJ, et al. Isolation of biologically active ribonucleic acid from sources enriched in ribonuclease. Biochemistry 1979;18:5294-5299.

36. Ramadori G, Sipe JD, Dinarello CA, et al. Pretranslational modulation of acute phase hepatic protein synthesis by murine recombinant interleukin 1 (IL-1) and purified human IL-1. J Exp Med 1985;162: 930-942.

37. Wang $\mathrm{RH}, \mathrm{Li} \mathrm{C}, \mathrm{Xu} \mathrm{X}$, et al. A role of SMAD4 in iron metabolism through the positive regulation of hepcidin expression. Cell Metab 2005:2:399-409.

38. Lee P, Peng H, Gelbart T, et al. The IL-6- and lipopolysaccharideinduced transcription of hepcidin in HFE-, transferrin receptor 2-, and beta 2-microglobulin-deficient hepatocytes. Proc Natl Acad Sci USA 2004;101:9263-9265.

39. Christiansen $\mathrm{H}$, Sheikh $\mathrm{N}$, Saile B, et al. x-Irradiation in rat liver: consequent upregulation of hepcidin and downregulation of hemojuvelin and ferroportin-1 gene expression. Radiology 2006;242:189-197.

40. Ganz T, Nemeth E. Iron imports. IV. Hepcidin and regulation of body iron metabolism. Am J Physiol Gastrointest Liver Physiol 2006;290:G199-G203.

41. Lee $\mathrm{P}$, Peng $\mathrm{H}$, Gelbart $\mathrm{T}$, et al. Regulation of hepcidin transcription by interleukin-1 and interleukin-6. Proc Natl Acad Sci USA 2005;102:1906-1910.

42. Wrighting DM, Andrews NC. Interleukin-6 induces hepcidin expression through STAT3. Blood 2006;108:3204-3209.

43. Pietrangelo A, Dierssen U, Valli L, et al. STAT3 is required for IL-6-gp130-dependent activation of hepcidin in vivo. Gastroenterology 2007;132:294-300.

44. Malyszko J, Malyszko JS, Pawlak K, et al. Hepcidin, an acute-phase protein and a marker of inflammation in kidney transplant recipients with and without coronary artery disease. Transplant Proc 2006;38:2895-2898. 
45. Frazer DM, Wilkins SJ, Millard KN, et al. Increased hepcidin expression and hypoferremia associated with an acute phase response are not affected by inactivation of HFE. Br J Haematol 2004;126:434-436.

46. Montosi G, Corradini E, Garuti C, et al. Kupffer cells and macrophages are not required for hepatic hepcidin activation during iron overload. Hepatology 2005;41:545-552.

47. Nicolas G, Chauvet $C$, Viatte $L$, et al. The gene encoding the iron regulatory peptide hepcidin is regulated by anemia, hypoxia, and inflammation. J Clin Invest 2002;110:1037-1044.

48. Sun XF, Zhou DB, Zhao YQ. An iron regulator hepcidin is affected by EPO. Zhongguo Shi Yan Xue Ye Xue Za Zhi 2006;14:778-782.

49. Kulaksiz H, Gehrke SG, Janetzko A, et al. Pro-hepcidin: expression and cell specific localisation in the liver and its regulation in hereditary hemochromatosis, chronic renal insufficiency, and renal anaemia. Gut 2004;53:735-743.

50. Tomosugi N, Kawabata H, Wakatabe $\mathrm{R}$, et al. Detection of serum hepcidin in renal failure and inflammation by using ProteinChip System. Blood 2006;108:1381-1387.

51. Roy CN, Andrews NC. Anemia of inflammation: the hepcidin link. Curr Opin Hematol 2005;12:107-111.

52. Bondi $A$, Valentino $P$, Daraio $F$, et al. Hepatic expression of hemochromatosis genes in two mouse strains after phlebotomy and iron overload. Haematologica 90;2005:1161-1167.

53. Hentze MW, Muckenthaler MU, Andrews NC. Balancing acts: molecular control of mammalian iron metabolism. Cell 2004;117:285-297.

54. Chen H, Su T, Attieh ZK, et al. Systemic regulation of hephaestin and Ireg1 revealed in studies of genetic and nutritional iron deficiency. Blood 2003;102:1893-1899.

55. Cairo G, Pietrangelo A. Transferrin receptor gene expression during rat liver regeneration. Evidence for post-transcriptional regulation by iron regulatory factorB, a second iron-responsive element-binding protein J Biol Chem 1994;269:6405-6409.

56. Fleming RE, Britton RS. Iron imports. VI. HFE and regulation of intestinal iron absorption. Am J Physiol Gastrointest Liver Physiol 2006:290:G590-G594.

57. Lebron JA, Bennett MJ, Vaughn DE, et al. Crystal structure of the hemochromatosis protein HFE and characterization of its interaction with transferrin receptor. Cell 1998;93:111-123.
58. Bridle KR, Frazer DM, Wilkins SJ, et al. Disrupted hepcidin regulation in HFE-associated hemochromatosis and the liver as a regulator of body iron homoeostasis. Lancet 2003;361:669-673.

59. Muckenthaler M, Roy CN, Custodio AO, et al. Regulatory defects in liver and intestine implicate abnormal hepcidin and Cybrd1 expression in mouse hemochromatosis. Nat Genet 2003;34: 102-107.

60. Jacolot S, Le Gac G, Scotet V, et al. HAMP as a modifier gene that increases the phenotypic expression of the HFE pC282Y homozygous genotype. Blood 2004;103:2835-2840.

61. Donovan A, Brownlie A, Zhou Y, et al. Positional cloning of zebrafish ferroportin1 identifies a conserved vertebrate iron exporter. Nature 2000;403:776-781.

62. Fleming RE, Migas MC, Zhou X, et al. Mechanism of increased iron absorption in murine model of hereditary hemochromatosis: increased duodenal expression of the iron transporter DMT1. Proc Natl Acad Sci USA 1999;96:3143-3148.

63. Han O, Fleet JC, Wood RJ. Reciprocal regulation of HFE and Nramp2 gene expression by iron in human intestinal cells. J Nutr 1999;129: 98-104.

64. Wardrop SL, Richardson DR. The effect of intracellular iron concentration and nitrogen monoxide on Nramp2 expression and non-transferrin-bound iron uptake. Eur J Biochem 1999;263: 41-49.

65. Muckenthaler M, Gray NK, Hentze MW. IRP-1 binding to ferritin mRNA prevents the recruitment of the small ribosomal subunit by the cap-binding complex elF4F. Mol Cell 1998;2:383-388.

66. Binder R, Horowitz JA, Basilion JP, et al. Evidence that the pathway of transferrin receptor mRNA degradation involves an endonucleolytic cleavage within the $3^{\prime}$ UTR and does not involve poly(A) tail shortening. EMBO J 1994;13:1969-1980.

67. Kawabata $H$, Yang $R$, Hirama $T$, et al. Molecular cloning of transferrin receptor 2. A new member of the transferrin receptor-like family. J Biol Chem 1999;274:20826-20832.

68. Fleming RE, Migas MC, Holden CC, et al. Transferrin receptor 2: continued expression in mouse liver in the face of iron overload and in hereditary hemochromatosis. Proc Natl Acad Sci USA 2000;97: 2214-2219. 